\title{
Physcomitrium patens: A Single Model to Study Oriented Cell Divisions in 1D to 3D Patterning
}

\author{
Jeroen de Keijzer $1,+\left(\mathbb{C}\right.$, Alejandra Freire Rios ${ }^{1,2,+}+\mathbb{C}$ and Viola Willemsen $2, *(\mathbb{C}$ \\ 1 Laboratory of Cell Biology, Department of Plant Sciences, Wageningen University \& Research, \\ 6708 PB Wageningen, The Netherlands; Jeroen.deKeijzer@wur.nl (J.d.K.); alejandra.freirerios@wur.nl (A.F.R.) \\ 2 Laboratory of Molecular Biology, Department of Plant Sciences, Wageningen University \& Research, \\ 6708 PB Wageningen, The Netherlands \\ * Correspondence: viola.willemsen@wur.nl \\ + These authors share the first authorship.
}

check for updates

Citation: de Keijzer, J.; Freire Rios, A.; Willemsen, V. Physcomitrium patens: A Single Model to Study Oriented Cell Divisions in 1D to 3D Patterning. Int. J. Mol. Sci. 2021, 22, 2626. https://doi.org/10.3390/ ijms22052626

Academic Editor: Adriana Basile

Received: 9 February 2021

Accepted: 25 February 2021

Published: 5 March 2021

Publisher's Note: MDPI stays neutral with regard to jurisdictional claims in published maps and institutional affiliations.

Copyright: (c) 2021 by the authors. Licensee MDPI, Basel, Switzerland. This article is an open access article distributed under the terms and conditions of the Creative Commons Attribution (CC BY) license (https:// creativecommons.org/licenses/by/ $4.0 /)$.

\begin{abstract}
Development in multicellular organisms relies on cell proliferation and specialization. In plants, both these processes critically depend on the spatial organization of cells within a tissue. Owing to an absence of significant cellular migration, the relative position of plant cells is virtually made permanent at the moment of division. Therefore, in numerous plant developmental contexts, the (divergent) developmental trajectories of daughter cells are dependent on division plane positioning in the parental cell. Prior to and throughout division, specific cellular processes inform, establish and execute division plane control. For studying these facets of division plane control, the moss Physcomitrium (Physcomitrella) patens has emerged as a suitable model system. Developmental progression in this organism starts out simple and transitions towards a body plan with a three-dimensional structure. The transition is accompanied by a series of divisions where cell fate transitions and division plane positioning go hand in hand. These divisions are experimentally highly tractable and accessible. In this review, we will highlight recently uncovered mechanisms, including polarity protein complexes and cytoskeletal structures, and transcriptional regulators, that are required for $1 \mathrm{D}$ to $3 \mathrm{D}$ body plan formation.
\end{abstract}

Keywords: asymmetric cell division; proliferative cell division; division plane positioning; Physcomitrium; gametophore initiation

\section{Introduction}

Proper development of three-dimensional multicellular organisms requires accurate relative positioning of cells and acquisition of new cellular identities. These processes drive the formation of tissues with specialized functions that allow organisms with higher complexity. The placement of new cells follows a robust plan/blueprint in order to achieve anatomies specific for each species. In plants, cellular migration is extremely limited because cells are encased in their cell walls. Therefore, plant development relies on controlled directional cell expansion and changes in the orientation of their division plane. For this, cells must have accurate spatial information prior to initiating formative divisions, including cues with respect to organ/organismal axes and cellular polarization. Disordered formative divisions early in development can be lethal, and later ones can seriously affect the formation of important organs, affecting survival and reproduction [1-5].

With the importance of accurate spatial information to position the division plane during asymmetric divisions in plants, uniquely tailored and fascinating cellular mechanisms that generate and interpret this information have come to light. Conceptually, three phases can be distinguished where such mechanisms are active (summarized in Figure 1). Firstly, before division, information that can break symmetry along a particular cellular axis within the parental cell must be established. Both cell-intrinsic factors and extrinsic factors supply this information (Figure 1A). Cell-intrinsic factors are required for internal 
symmetry breaking and often function via cortically located polarity protein complexes. Cell-extrinsic factors include cues from surrounding tissue that are mostly biochemical but also mechanical in nature. In plants, the continued exposure of daughter cells to extrinsic positional information is typically also involved in driving further cell fate divergence after division has taken place [6]. Cell-intrinsic and extrinsic factors are not independent and can operate synergistically or antagonistically in providing positional information [7].

A

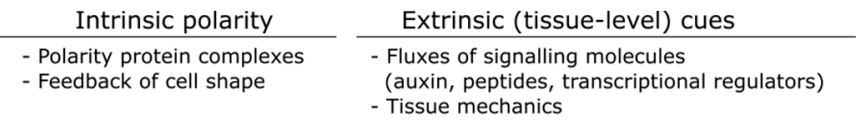

Signalling

mechanisms that generate spatial

information
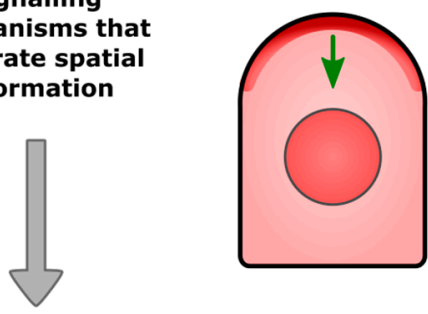

B

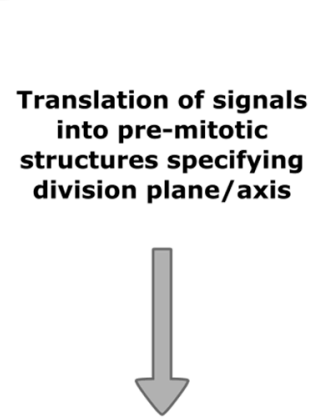

C

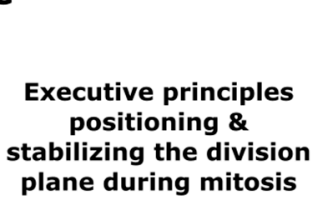

Cortical division zone (CDZ) specification
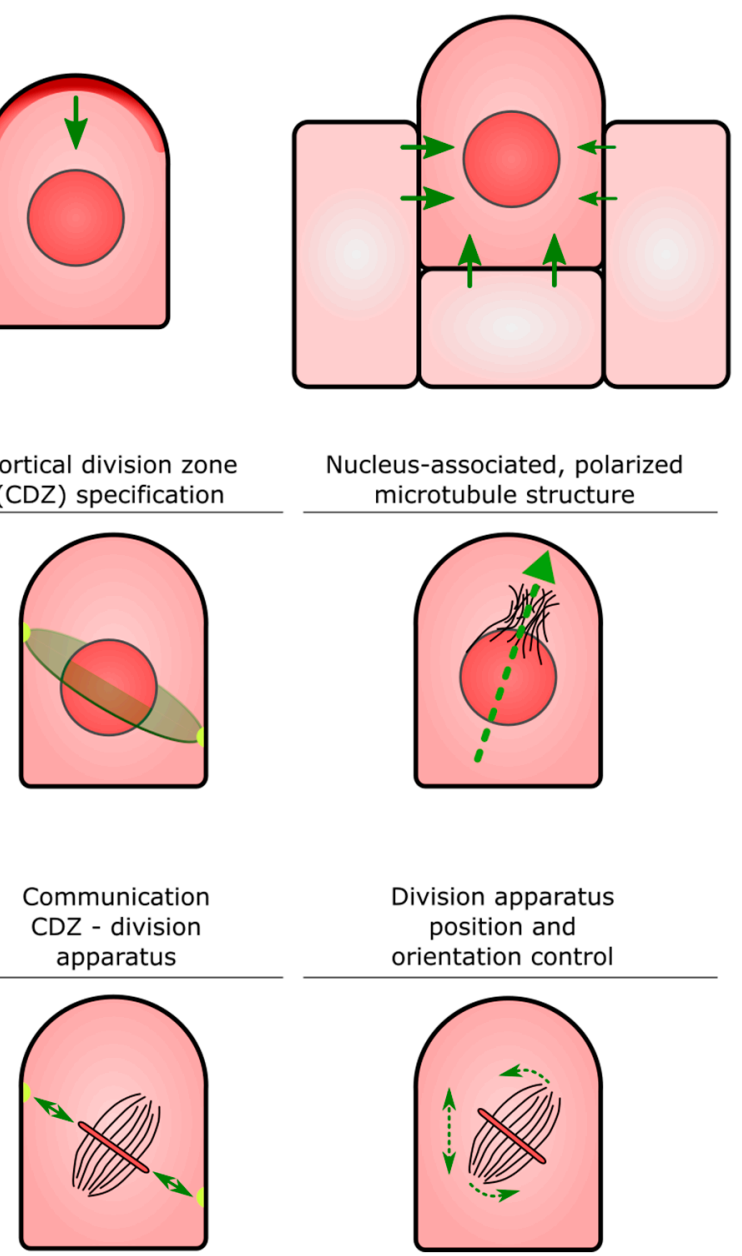

Figure 1. Generalized schematic representation of the processes and factors necessary for correct positioning of division planes during (asymmetrical) plant cell division. (A) For a parental cell to polarize, positional information is required. Positional information is generated by both cell-intrinsic factors (left) and extrinsic factors from surrounding tissues (right). Cell-intrinsic factors chiefly act at the cell cortex, where they can establish polarized signaling domains (red). Extrinsic signaling occurs via (unequal) exposure to cues, examples of which are provided. (B) As the parental cell is about to undergo mitosis, specific structures arise that will instruct the prospective division apparatus on the position and orientation of the desired division plane. The most prominent structure is the cortical division zone (CDZ; light green) that marks the partitioning plane (left). Additionally, polarized microtubule structures that are associated with the nucleus affect the axis along which division will take place (right). (C) As mitosis is executed, continuous control over the position and orientation of the division apparatus is required for proper division plane control (right). Final guidance of the division apparatus constructing the nascent dividing wall towards the CDZ is achieved by physical and/or biochemical communication between these two structures (left). 
Secondly, just prior to mitotic onset, the symmetry-breaking cues are translated into processes that anticipate the selected division plane. These chiefly include nuclear positioning and the establishment of structures that help specify the orientation of the incipient division apparatus (Figure 1B). A prominent structure involved in the latter is a specialized zone at the cell cortex that acts as a division plane landmark (termed the "cortical division zone"; see glossary). The cytoskeleton plays important roles in the formation of such pre-mitotic structures involved in division plane specification. Finally, as cell division is executed, the position and orientation of the division apparatus is actively controlled (Figure 1C). The new dividing wall is formed in the final stages of division by the phragmoplast (see glossary). Its communication with the previously specified cortical domain then fine-tunes the final orientation of the dividing wall separating the two daughter cells (Figure 1C).

In this review, we focus on recent research covering several major mechanisms and molecular players that function during these three phases to control plant asymmetric cell divisions. This will be complemented by a brief discussion of the key transcriptional and hormonal regulators that trigger and govern asymmetric cell division. We will focus specifically on how various developmental steps in the bryophyte Physcomitrium patens (P. patens) can collectively provide a well-suited platform to aid in the study of asymmetric cell division. P. patens also benefits from a host of molecular genetic tools and a simple body plan with mostly monolayered tissues and organs that are easily accessible by microscopy.

Glossary

- Formative cell division: cell division that generates daughters with different identities; also called formative asymmetric cell division (ACD).

- Proliferative cell division: cell division that generates daughters of the same identity; also called symmetric cell division (SCD).

- Cell fate/cell identity: commitment to cell type-specific genetic programs.

- Cell division plane: Actual or forecast plane physically separating two daughter cells.

- Symmetry-breaking/cellular polarization: unequal distribution of molecules and cellular components. Required for important processes like differential cell fate acquisition of two daughter cells.

- Cortical Division Zone (CDZ): A membrane and cell wall-associated domain at the cell cortex established at or just before mitotic entry that specifies a plane in the parental cell through which daughter cells will ultimately be partitioned (see also Figure 1B). The CDZ has a dynamic composition that includes cytoskeletal and membrane-bound components, and functions as landmark for the correct insertion of the nascent dividing wall constructed by the phragmoplast.

- $\quad$ Pre-prophase band (PPB): Ring-shaped assembly of the microtubule cytoskeleton and associated proteins that transiently appears before the onset of cell division. The overall orientation of the PPB appears to be inherited from that of the interphase cortical microtubules, and its position correlates with that of the CDZ.

- Phragmoplast: Plant-specific cellular apparatus that brings about physical separation of two newly formed daughter cells (cytokinesis) at the end of cell division. It consists of two opposing sets of microtubules, in the center of which, small, membranous building blocks are assembled into a radially expanding precursor of the new dividing wall. Insertion of this precursor at the parental wall occurs at the site specified by the CDZ.

\section{Developmental Stages of P. patens Are Marked by Characteristic Cell Divisions and Establishment of New Growth Axes}

At the start of its lifecycle (i.e., after a spore germinates), a moss plant establishes itself by outgrowth of filamentous tissue, called protonemata (Figure 2A). These filaments consist of two types: a slow-growing, photosynthetically active type and a rapidly expanding type with underdeveloped chloroplasts, called chloronemata and caulonemata, respectively. Both types expand exclusively by highly polarized tip growth to effectively explore 
the plant's immediate environment [8]. Initially, primary filaments have a chloronemal identity, which, after several division rounds of the tip cell, can transition to a caulonemal identity. Notably, the division planes in chloronemata are perpendicular to the growth axis, while those in caulonemata are consistently slanted (Figure 2(B1)). The physiological or developmental relevance of the slanted cross walls for the organism has not yet been established. The chloronema-to-caulonema identity transition is controlled by the plant hormone auxin and a set of conserved transcription factors [9,10]. Interestingly, auxin signaling is important for division plane positioning in other plant systems [11,12], hinting that similar roles may be encountered in moss. Overall, the simple patterning and unidirectional expansion of these filamentous tissues allows us to address fundamental questions regarding developmental decisions taking place at the (sub)cellular level, such as polarity formation and division plane control.

Further developmental progression in the protonemal filament relies on branching. Here, a new growth axis is established on a pre-existing filament, allowing the tissue to expand in a second dimension (Figure 2(B2); recently reviewed in [13]). Branching is initiated by a subapical cell and is under the control of hormonal and carbon-related signaling $[10,14,15]$, although it also shows probabilistic elements, with a variable frequency of branching occurring in a typical filament. Branching normally occurs on the apexdirected side of a mother cell and is oriented according to environmental inputs like gravity and light $[16,17]$. Prior to visible outgrowth of a new branch, the mother cell undergoes intracellular reorganization (cell polarization) to bring its nucleus and cell division machinery towards the designated branching site. Recent work has established that cell polarization is relayed through Rho of plants (ROP) proteins, and that nuclear guidance by actin and microtubules plays a major role during the branching process (see Section 3.1) $[18,19]$. The formed outgrowth will be separated from the subapical mother cell at the moment of cell division and continues to grow at its tip as a secondary protonemal apical cell.

During the juvenile protonemal stage, development of so-called buds is initiated. These buds give rise to leafy shoots with three-dimensional tissue growth, on top of which the gamete-forming organs are ultimately formed; hence their name, gametophores (Figure 2A). Buds are initiated on older subapical caulonemal cells by the formation of a bulge similar to that during a branching event. Contrary to branching, though, after an initial transition division, the bulge will instead swell in a diffuse manner and then divide in an oblique manner. This oblique division will generate an apical-basal and medial-lateral axis [20] (Figure 2(B3)). Subsequent divisions initiate three-dimensional development proper and are precisely positioned to give rise to a tetrahedral apical cell (further discussed below), which principally drives further gametophore development $[20,21]$. Thus, a series of asymmetric divisions accomplishes the transition to the 3D body patterning of the more mature gametophore tissues from a precursor tissue with a 2D growth mode. Despite the similarities between branch formation and bud initiation on a protonemal parental cell, the morphology of the outgrowth and the angle of the division plane distinguish the two $[20,22]$. The switch to the gametophore developmental program involves several distinct layers of transcriptional and hormonal regulation (indicated by yellow nuclei in Figure 2B; reviewed in [23] and further discussed in Sections 6 and 7). However, the precise moment the competency of a subapical caulonemal cell to produce buds is determined is unclear, but fate determination seems at least to be initiated in the parental cell before the division leading to this transition takes place [22]. 
A

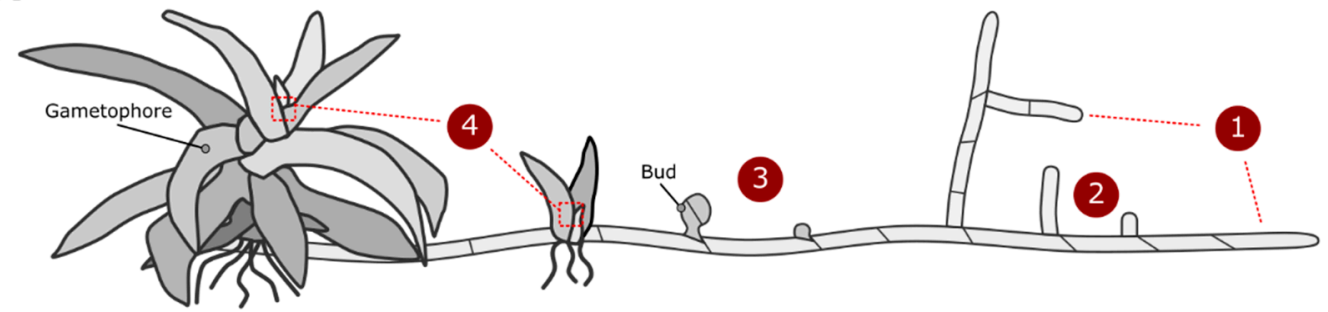

B
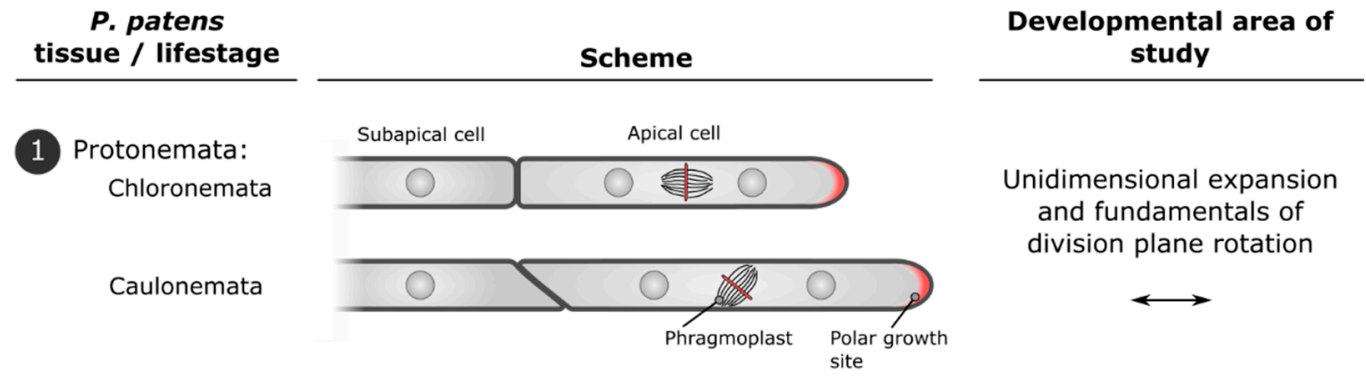

2 Protonemal

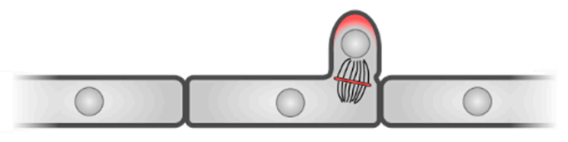

New body axis specification Organelle migration branching

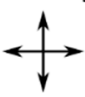

2D to 3D transition

3 Gametophore bud transition division and bud initiation
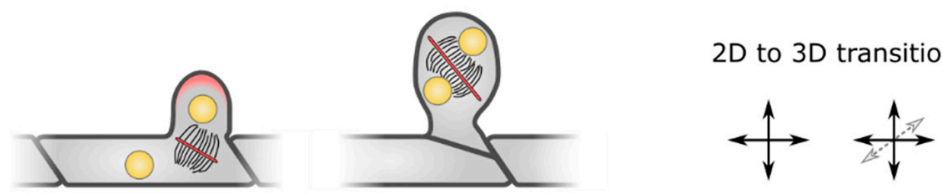

3D formative divisions

Tetrahedral apical cell in gametophore apex
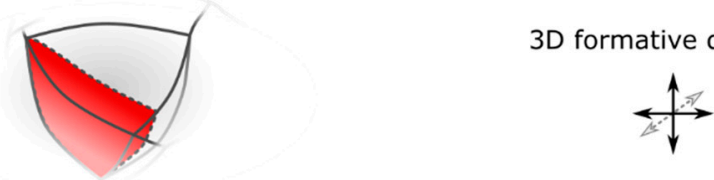

Figure 2. Developmental progression in Physcomitrium patens and the accompanying cellular phenomena that can be studied. (A) Schematic overview of stages in P. patens (gametophytic) development. Cellular outlines (protonemata/buds) or tissue outlines (gametophores) are depicted. Tissue types predominantly associated with juvenile up to adult phases are arranged right to left. Numbers correspond to particular tissues and/or life stages, with oriented cell divisions leading to tissue type specification or changes in growth axes that are further detailed in B. (B) Four P. patens tissues/life stages where various aspects of cell division plane orientation and the establishment of new organismal axes can be studied: (1) Two types of filamentous protonemata (chloronemata + caulonemata) both grow by polarized, unidimensional cell expansion at their apex. The former produces division planes (red line) perpendicular to the growth axis, while the latter exhibits tilting of the division apparatus (phragmoplast), leading to slanted division planes. (2) A secondary growth axis (indicated by arrows) within protonemal tissue can be established by branching of subapical cells. This involves cell polarization and control over nuclear position and division plane orientation. (3) From the juvenile protonema, a transition to 3D developing gametophores can be initiated. This starts by outgrowth of a bud accompanied by cell divisions with specific division plane orientations that establish new organismal axes. Initiation of this developmental program is regulated by distinct transcriptional and hormonal pathways (indicated by yellow nuclei). (4) The apex of the bud ultimately gives rise to a singular stem cell with three cutting faces (one is indicated). Its continued production of daughter cells and their further developmental trajectories drive gametophore morphogenesis.

The tetrahedral cell at the apex of a gametophore fulfils a meristematic function to drive shoot growth and development. This tetrahedral cell has four sides, along three of which, consecutive cutting faces produce daughter cells (Figure 2(B4)). The overall division plane orientations of the consecutive divisions rotate slightly left- or right-handed with 
respect to the main axis of the stem [24]. The positioning of these divisions planes is likely very precise, as it underpins the phyllotactic pattern of the gametophore (reviewed in [25]).

\section{Signaling Molecules Driving Cell Polarization in Moss}

Several protein families and protein domains involved in cell polarity are conserved across kingdoms, suggesting the presence of conserved underlying molecular mechanisms. Here, we discuss some of these major protein families and how they act as intrinsic cellular cues for cell polarity in land plants.

\subsection{ROPS}

Small GTPases (Rho, Rac and CDC42) are highly conserved in yeast and animals. Small Rho-GTPases are known as master regulators of cell polarity in eukaryotes. They serve as a positioning cue, having effects in several subcellular processes like re-arrangement of cytoskeleton elements and exocytosis (reviewed in [26]).

In land plants, a family of small GTPases (Rho of Plants (ROPs)) is also present; however, they are sometimes referred to as RACs. Like other small GTPases, ROP/RACs have a GTPase catalytic domain that allows them to transition from a GDP-bound inactive to a GTP-bound active state. Active ROPs cluster membrane domains to which they can attach via lipid modifications of their C-terminus. Upstream of ROPs, ROP guanidine exchange factors (ROP-GEFs) promote their activation at the membrane. Active ROPs can regulate different effector proteins, ultimately controlling subcellular events involved in many different biological processes (pathogen responses, hormone responses, cell growth, etc.; reviewed in [26]). One important family of plant-specific ROP effectors is named RICs (ROP-Interacting CRIB-containing proteins). RIC proteins are characterized by containing the ROP-interactive CRIB (Cdc42-and Rac-Interactive Binding) motif, which is able to physically interact with GTP-bound ROPs. Different functions have been assigned to few members of the Arabidopsis RIC family that involve cytoskeleton reorganization (either actin or microtubule filaments) $[27,28]$. Based on sequence homology, there is only one putative RIC protein in P. patens [29]. Sequences encoding for RIC proteins were not found in the genomes of other members of the bryophyte clade, hornworts and liverworts (Freire-Rios, unpublished).

While ROPs have been shown to have a mechanistic role for some specific plant formative divisions (e.g., stomata formation in monocots [30]), it is not clear if they are necessary for cell fate specification, as was demonstrated in animals [31]. The fact that this has never been successfully shown in plants could be due to the high number of ROP family members and their redundant functions in model flowering plants. P. patens, with only four almost identical ROP protein family members, has been proposed as a model to study the role of ROPs and their effectors. Recently, it has been suggested that accumulation of tagged PpROP4 not only predicts the sites of filamentous outgrowth (tips and branches), but also the position of new division planes in protonema filaments during cell divisions $[18,19]$. Because PpROP4 protein accumulation precedes and is partly responsible for nuclear movement towards the division site during filament branching [18,19], it has been speculated that PpROP4s act on microtubule organization. However, the underlying molecular mechanisms of these responses remain unknown. In an ongoing study specifically focused on asymmetric cell divisions in P. patens, it was observed that deletion of one of the PpROP members leads to plants hampered in establishing filaments with a caulonema identity, and abnormally shaped gametophores. Interestingly, these defects are rescued by the deletion of the single putative PpRIC effector (Freire-Rios, unpublished). More broadly in bryophytes, a study in Marchantia polymorfa (a liverwort) showed a role for ROP signaling in plant development [32]. The downstream mechanism, though, has not yet been described. 


\subsection{SOSEKIs}

The SOSEKI family of polarly localized proteins has been recently identified and is conserved in land plants ([33,34]. Originally identified in Arabidopsis, each of the five family members in this species was found to accumulate in a different corner of the cell, from which the name SOSEKI (Japanese for "cornerstone") was derived [34]. SOSEKIs represent an outstanding and intriguing class of polar proteins because their accumulation appears to be independent of the conventional cellular trafficking pathways involved in polar protein delivery [34]. Functionally dissecting the constituent protein domains revealed that SOSEKIs associate with the plasma membrane at specific cell edges via a centrally located domain, where they oligomerize via their $N$-terminal domain. Collectively, these properties lead to their highly polarized accumulation at cell corners [33,34]. The $\mathrm{N}$-terminal oligomerization domain is functionally equivalent to the DIX domains found in the animal kingdom. In animals, DIX domains are broadly involved in forming a polarized scaffold during planar polarity signaling also via oligomerization. The oligomerization functions to effectively recruit downstream signal transduction components, despite low individual protein-protein affinities between DIX-containing proteins and such components. Analogous SOSEKI-associated signaling components in plants are beginning to be discovered. In Arabidopsis, ANGUSTIFOLIA (AN) has been identified as a factor recruited by SOSEKIs. Since $A N$ mutants show polarity-related phenotypes, like rounded cells and misorientation of cell division planes $[35,36]$, its SOSEKI association could be an important aspect of its functioning.

An ancestral role of SOSEKIs within the land plants is strongly suggested by the highly similar behavior of labeled SOSEKIs in the bryophytes Marchantia polymorpha and P. patens [33]. The SOSEKI family of P. patens (PpSOKs) consists of 11 members and, so far, the subcellular localization of four members has been analyzed. Two out of these four PpSOKs show polar subcellular localization. Notably, one of the analyzed members, PpSOK2, is absent during filamentous growth but is specifically observed during early 3D bud and gametophore leaf development. This suggests some form of specificity in the functionality of SOSEKI protein family members in P. patens. Further study of such members with a clear correlation to certain developmental steps could help elucidate their role in 3D moss development and establish the degree of functional conservation of SOSEKIs more broadly.

\section{Peptide-Mediated Intercellular Signaling during Moss Development}

Extrinsic cues and their perception mechanisms are important to relay information on the tissue context and surroundings to an asymmetrically dividing cell. Furthermore, the transmission of molecules can play an important role in the establishment or maintenance of cellular identities after the division has taken place [37]. It has been shown, for example, that in flowering plants, intercellular movement of transcription factors and microRNAs plays a role in cell identity acquisition and maintenance (reviewed in [38]), but in mosses, this remains a widely unexplored field and will not be covered in this review. So far, signaling through small peptides remains the most studied form of intercellular communication in mosses.

An evolutionary conserved module involved in the spatial coordination of stem cell proliferation consists of small secreted chains of amino acids (peptides) and their cognate membrane-bound receptor proteins. The peptides belong to the CLAVATA3 (CLV3)/EMBRYO SURROUNDING REGION-related (CLE) family and are ligands for plasma membrane-located leucine-rich repeat receptor-like kinases (LRR-RLKs). Upon CLE perception, the LRR-RLKs typically modulate the proliferative activity of a stem cell population, although some CLE-LRR-RLK combinations function in other developmental and physiological processes as well (reviewed by $[39,40]$ ). Since the CLE peptides can freely diffuse in the apoplastic space, they often relay information between neighboring cells. This spatial aspect of CLE-mediated signaling has been found to be able to fulfil dual roles in the various meristems found in seed plants. Firstly, it generates a feedback loop 
between the different zones of a meristem such that stem cell homeostasis can be coordinated [39]. This was first described for the shoot apical meristem [41] and later appeared to be recurrent in root meristems as well [42]. Secondly, it was found that in vascular meristems, a CLE gradient provides instructions for division plane determination [43]. Thus, the CLE-LRR-RLK module constitutes a bona fide intercellular communication relay to orient formative cell divisions (such as that outlined in Figure 1B). Intriguingly, this function was found to also occur in bryophyte species, including P. patens [44,45]. In moss, loss of CLE and LRR-RLK function led to the misplacement of division planes, starting during the earliest developmental steps of gametophore initiation [45]. This suggests that instructing the orientation of the division plane during 3D development could be an ancestral function of the CLE-LRR-RLK signaling module. Which downstream components are used by the cell to implement the positional instructions conveyed by the CLE gradient are currently unknown. This prominent open question could be addressed using P. patens bud development as a simple and accessible model.

\section{Role of the Cytoskeleton in Division Plane Control}

The cytoskeleton is one of the key structural components to bring about cell division, and thus many regulatory mechanisms for division plane control appear to impinge on these subcellular components. In the context of asymmetric division, they are thus notable candidates to convert internal and external cues into the required division plane position/orientation. Classically, in seed plants, two microtubule configurations have been strongly connected to designate and build a new division site. The first is the microtubule array that develops from the mitotic spindle and brings about construction of the separating wall between the two nascent daughter cells: the phragmoplast (see glossary). The function of the phragmoplast is to assemble smaller building blocks supplied by the secretory system into a straight, disc-shaped precursor of the dividing wall [46]. The second is a microtubular ring in the form of the preprophase band (PPB) that forecasts the division plane prior to the start of cell division proper. While the PPB microtubule structure is transient, its position and orientation coincide with a ring-shaped domain at the plasma membrane with a specialized molecular makeup that persists throughout mitosis, called the cortical division zone (CDZ; see glossary). Although dynamic, the CDZ fulfils the role of a "molecular memory" to guide expansion of the phragmoplast such that, ultimately, the nascent wall connects to the parental wall at the CDZ-defined position. For recent comprehensive reviews on the CDZ's molecular makeup and function, see [47-50].

A generalized causal role for PPB microtubules in defining the CDZ is currently unclear. On the one hand, the net orientation of microtubules at the cellular cortex which is preserved by the PPB correlates well with decisions about where to position the division plane [51-53]. Furthermore, under dynamic reorientation of cortical microtubules in response to changing cell shapes or mechanical stress patterns, the PPB maintains an indicator role for division plane positioning [54,55]. On the other hand, however, findings in the Arabidopsis root have established that PPB microtubules are not prominently required for division plane selection and $\mathrm{CDZ}$ establishment, but instead fine-tune the plane [56,57]. Consistently, important CDZ markers like POK1 (Phragmoplast Orienting Kinesin 1) localize correctly in absence of PPB microtubules, albeit less efficiently [56]. It is thus highly conceivable that PPB-independent mechanisms convey information towards "imprinting" of the CDZ and thus the division plane selection process, possibly still incorporating orientational information from earlier cortical microtubule arrays. A prime future challenge will thus be to explore such alternate mechanisms and expose the molecular pathways involved.

Physcomitrium has the potential to broaden our knowledge on how pre-mitotic microtubular constellations and tentative alternatives function during division plane establishment. In P. patens, divisions in protonemata and early gametophore development do not exhibit a PPB, whereas those in later gametophore tissues do $[21,58,59]$. This transition in presence of a PPB is mirrored by a pronounced role for the functionally conserved 
regulator of PPB formation TONNEAU1 later in the moss lifecycle, chiefly during leaf development [60]. However, precisely controlled divisions still take place in early moss development. For example, the tilting of the division plane in caulonemal cells (Figure 2(B1)) is partly affected by external cues like gravity [16], signifying that molecular pathways must be in place to establish a deviating division plane. Similarly, bud development relies on finely tuned division planes that take place in absence of PPBs [20,21]. This must thus mean that PPB-independent mechanisms are operational in these tissues.

One such pre-mitotic structure with clear links to division plane determination is a cytoplasmic cloud of microtubules typically associated with one (but occasionally more) side of the nucleus [21,59]. Using early bud development as a model of oriented cell division, chemical disruption of the cloud highlighted its role in correctly initiating the main axis of the spindle and subsequent phragmoplast [21]. The spatial information provided by this structure thus seems vectoral in nature (Figure 1C). Whether there is an interplay with any cortically located division plane determinants remains unknown, as these have not yet been identified in bud development. In the later developmental stages of moss, where PPBs are formed, the cytosolic microtubule clouds are still observed, although, here, their functional relevance is unexplored [21]. Whether the lack of a canonical PPB microtubule configuration in certain moss tissues represents an evolutionary loss (and is thus a derived state) or whether it is indicative of ancestral mechanisms that evolved earlier is currently unknown. The fact that moss presents us with a gradient of two distinct preprophase microtubule configurations that both function in establishing division plane orientation will allow us to better study and ultimately understand how diverse coupling mechanisms between pre-mitotic cytoskeletal structures and division plane specification evolved and function.

Beyond pre-mitotic events providing landmarks or setting the initial conditions for the division apparatus, continued control over its position and axis is required. The cytoskeleton and associated proteins are generally implicated in control of these parameters [50,61]. In the study of these processes, the divisions in P. patens protonemata and buds have proven to be experimentally accessible models. For example, recent findings show that the microtubule-associated protein TPX2 is essential for maintenance of a central spindle position along the apical-basal axis in buds [62]. This defect could surprisingly be compensated by actin cytoskeleton disruption, which, under normal conditions, does not significantly interfere with spindle/phragmoplast positioning [21,62]. These findings open new avenues for study on the mechanisms controlling "tugging" of the division apparatus during mitosis and its implications for division plane positioning. Another principle that positions the division apparatus involves its communication with the CDZ. In protonemal moss cells, a physical link between the two, mediated by actin and associated myosin Class VIII motor proteins, is established, which assists in division plane guidance [63]. Such cytoskeletal bridging between the CDZ and the division apparatus is documented in diverse other plants as well $[47,64]$. High-resolution imaging and in vitro reconstitution experiments are currently promising techniques to deliver the details on the distances across which bridging acts, and how and where the required forces are generated [65].

\section{Cellular and Transcriptional Signal Transduction Mechanisms for Asymmetric Cell Divisions}

The different (sub)cellular phenomena setting up polarity axes and executing asymmetrical divisions discussed above are under the control of biochemical and genetic regulation. Since asymmetrical divisions typically participate in distinct steps of plant developmental programs, they must be effectively wired into developmental signaling mechanisms. Several biochemical, transcriptional and hormonal regulators that facilitate this in land plants in general and P. patens in particular have come to light.

\subsection{Defective Kernel1}

A pivotal and intensively investigated protein required for setting up the correct division planes during land plant development and cell type specification is DEK1 (Defective 
Kernel 1). The name Defective Kernel 1 is derived from a class of maize mutants with a defective endosperm, in which the gene was first isolated [66,67]. It later appeared that the protein family founded by maize DEK1 was highly conserved across land plants. DEK1 family proteins all share an $N$-terminal region of several membrane-spanning domains and a C-terminal cysteine protease moiety homologous to calpain proteases. The membraneassociated domain has been implicated in responsiveness to external stimuli, while the calpain protease confers most, if not all, the biological activity required for downstream signaling [68-70]. Findings from various plant systems broadly connect DEK1 function to the correct formation and specification of new cell layers at the boundary of plant organs during early development (e.g., aleurone and epidermal layers) [71-74]. The embryo lethality of many DEK1 mutants in seed plants has, however, made cellular and molecular details of DEK1 functioning sparse.

Recently, further mechanistic study of DEK1-type protein function has been greatly expedited on two fronts by functional analysis of P. patens, DEK1 (PpDEK1). Firstly, the evolutionary trajectory of $P$. patens as representative of a basal land plant branch, enabled comparative studies within the land plant clade that clearly established the functional conservation of the calpain protease domain of PpDEK1 with its orthologs in flowering plants [69]. Secondly, because PpDEK1 specifically functions during and after the transition to $3 \mathrm{D}$ growth and the 2D protonemata are sufficient for laboratory manipulation, PpDEK1 null mutants are not lethal. This makes $P$. patens an attractive model organism for dissecting DEK1 molecular pathways. So far, this has been exploited to establish the roles of several subdomains in the protein and their interoperability within the protein family $[75,76]$. Furthermore, by combining the precise embedding of a fluorophore tag within the DEK1 protein with live-cell imaging, a highly polarized distribution of PpDEK1 to the faces of recently divided cells was discovered during bud formation [77]. These advances illustrate how the diverse body pattern transitions and molecular genetic toolkit of $P$. patens can benefit the study of key cellular processes involved in plant development. Overall, DEK1 is emerging as a transducer of critical intra- or extracellular signals to spatially coordinate formative divisions. Encouraging results have revealed that the stimulus for DEK1 could be mechanical in nature [68]. Further open challenges remain, such as the elucidation of the downstream target(s) of the calpain protease domain, and the cause and functional relevance of the subcellular polarization.

\subsection{Transcriptional Regulation by APBs}

Transcriptome analysis comparing wild-type $P$. patens with $\Delta$ dek1 revealed various putative downstream genes, including family members of the AINTEGUMENTA, PLETHORA and BABY BOOM (APB) AP2-type transcription factor family that have orthologs in Arabidopsis. Specifically, the expression analysis showed upregulation of PpAPB2 and $P p A P B 3$ in lines where DEK1 was deleted [76], suggesting that their expression is repressed by PpDEK1. The in total four moss PpAPBs have collectively been shown to be indispensable for the initiation of gametophores from protonema cells. Quadruple $a p b$ knockout plants revealed budless protonemata, and overexpressing P $p A P B 4$ resulted in enhanced bud formation. Translational fusion of all PpAPBs to reporter proteins showed that they are expressed in emerging gametophore cells but not in secondary apical protonema cells. Taken together, these points indicate that one of the outputs of PpDEK1 downstream signaling might be the suppression of PpAPB-mediated gametophore initiation [76,78]. Furthermore, the ubiquitin-associated protein NO GAMETOPHORES 1 (PpNOG1) was found to positively regulate the number of gametophores formed and played a role in the orientation of the division plane [79]. A recent model for the regulation of three-dimensional growth in $P$. patens proposed that PpNOG1 and PpDEK1 act antagonistically to regulate the expression of $P p A P B$ genes [23].

PpAPBs orthologs in Arabidopsis belong to the PLETHORA/AIL (PLT) family of transcription factors. As in P. patens, the AtPLT family members show a high level of functional redundancy: single mutants do not show an obvious phenotype, while higher- 
order mutants exhibit phenotypes from ceased roots to embryo lethality. Overexpression of PLT2 in Arabidopsis induces cell divisions and reorientation of cell division planes (Willemsen, unpublished results). In Arabidopsis, PLTs are regulated via an autoregulatory feedback loop with auxin and the auxin efflux facilitators called PIN proteins to maintain an auxin gradient and root meristem function [80,81]. Furthermore, it has been shown that prolonged high auxin levels generate a narrow PLT transcription domain in the roots apical meristem. From there, it forms a PLT protein gradient which is generated through cell-to-cell movement and further diluted by cell divisions. The different levels of PLT proteins in the root define the different developmental zones of the root tip (i.e., high levels preserve the stem cell niche and promote cell division, whereas low levels result in cell differentiation) [82]. This indicates that PLT function is required for stem cell initiation, stem cell maintenance and cell division, as well as positioning the orientation of the cell division plane $[80,83]$ (Willemsen, unpublished results). P $P A P B S$ are also under control of auxin, which could indicate that this is a conserved functional link [78].

\section{Hormonal Regulation of Asymmetric Cell Divisions in Moss}

\subsection{Auxin}

The hormone auxin is a key factor for regulation of plant development, and it has been suggested that this function was adopted during the evolution of early land plants. Orthologs of the auxin sensing and response machinery like the TIR1/AFB-AUX/IAA co-receptors and three classes of the ARF transcription factors of Arabidopsis are conserved in bryophyte genomes [84-97]. Auxin movement in P. patens is mediated by efflux carriers, including the membrane-localized PINs [98,99]. The $P$. patens genome has three PIN homologs (PpPINA, PpPINB, PpPINC), which encode for proteins that are polarly localized in the plasma membrane $[98,99]$. Additionally, there is one atypical PIN version (PpPIND) which resides intracellularly at what is likely the ER membrane and resembles PIN5 in Arabidopsis [99]. PINA proteins are polarly localized in the membrane between the protonemal cells, with the highest abundance at the tip [99]. The localization of PpPINA-C is tipward, indicating that the source is probably located at the base of the colony and that auxin is transported towards the far end of the filament [10,99] PINA over-expressors show enhanced auxin export and branch numbers on caulonema cells, while pinapinb double mutants show reduced export but are not impaired in branch formation. This might indicate that the PIN proteins have highly overlapping functions and higher-order mutants are required to induce severe effects, like in Arabidopsis $[98,100]$. The chloronemato-caulonema transition is induced by auxin, indicating that auxin can change the identity of tip cells. This transition is also required to facilitate cells that can induce gametophore formation $[9,84,94,101]$. It was recently demonstrated in Arabidopsis that auxin can have a direct role in the establishment of plant cell polarity by promoting ROP clustering in membrane domains that could be locally activated [102-104]. This raises the question as to whether this could be a recurrent factor downstream of auxin during the regulation of cell division planes required for gametophore formation.

\subsection{Cytokinin}

It is known that the plant hormone cytokinin is involved in cell fate transition and bud formation, but hitherto, the underlying mechanism has been unknown. Different scenarios can be thought of, and one possibility is that the function of cytokinin is required for symmetry-breaking, as has been observed in Arabidopsis $[105,106]$. Additionally, in Arabidopsis, it has been shown that PLTs (via auxin) and the cytokinin response regulator (ARR12) antagonistically regulate each other to control cell size and organ growth [107]. In P. patens, it has been shown that $P p A P B$ genes activate cytokinin biosynthetic genes, which will induce the formation of initial gametophore cells [23]. Subsequently, a proposed feedback mechanism containing PpDEK1, PpNOG1 and CLAVATA makes sure that the divisions within the initial gametophore are oriented correctly [23,79]. Additionally, NO GAMETOPHORES 2 (PpNOG2) has been identified, and knockout mutants showed a 
misregulation of auxin-responsive genes [108]. New players that expand our knowledge on the feedback loops guiding gametophore formation are continuously being identified, but their precise spatio-temporal activity patterns remain unresolved.

\section{Future Directions}

The mechanisms that link the described cellular processes involved in division plane positioning and the overarching gene and hormone regulatory networks are only beginning to be understood. For instance, the links among cell polarity, cytoskeleton and transcriptional regulation is obscure. An important step towards understanding them is to identify new players in specific and accessible formative divisions. For this, a simple biological model and state-of-the-art techniques are required.

Our ability to observe events at the cellular level can be difficult in multi-layered organs of big, three-dimensional organisms (e.g., model flowering plants). Mosses instead offer researchers accessibility to a multitude of cell divisions of varying complexity during their lifecycle: 1D in filament extension, 2D in filament branching and 3D in bud formation (Figure 2). All are readily present during routine moss cultivation, but can also be experimentally halted or triggered by the researcher (e.g., by changing culture conditions or by hormonal induction).

Despite differences between the early cell divisions in branch- or bud-forming cells, the underlying molecular mechanisms specifying their fates is yet unknown. The characteristics that make moss an amenable system for cell biology studies should be accompanied by rigorously timed genetic expression studies that could provide early molecular markers of cell fate. We foresee that application of novel approaches like single cell sequencing will help with the identification of cell fate maps, opening up great avenues for the study of formative cell divisions and their molecular control during one- to three-dimensional plant body patterning.

Author Contributions: Conceptualization, J.d.K., A.F.R., V.W.; writing—original draft preparation, J.d.K., A.F.R., V.W.; writing—review and editing, J.d.K., A.F.R., V.W.; visualization, J.d.K. All authors have read and agreed to the published version of the manuscript.

Funding: This research received no external funding.

Institutional Review Board Statement: Not applicable.

Informed Consent Statement: Not applicable.

Data Availability Statement: The data presented in this study are available on request from the corresponding author.

Acknowledgments: We thank W. Kohlen and R. Heidstra for critically reading the manuscript.

Conflicts of Interest: The authors declare no conflict of interest.

\section{References}

1. Du, Y.; Scheres, B. PLETHORA transcription factors orchestrate de novo organ patterning during Arabidopsislateral root outgrowth. Proc. Natl. Acad. Sci. USA 2017, 114, 11709-11714. [CrossRef] [PubMed]

2. Camilleri, C.; Azimzadeh, J.; Pastuglia, M.; Bellini, C.; Grandjean, O.; Bouchez, D. The Arabidopsis TONNEAU2 Gene Encodes a Putative Novel Protein Phosphatase 2A Regulatory Subunit Essential for the Control of the Cortical Cytoskeleton. Plant Cell 2002, 14, 833-845. [CrossRef] [PubMed]

3. Traas, J.; Bellini, C.; Nacry, P.; Kronenberger, J.; Bouchez, D.; Caboche, M. Normal differentiation patterns in plants lacking microtubular preprophase bands. Nat. Cell Biol. 1995, 375, 676-677. [CrossRef]

4. Torres-Ruiz, R.A.; Jürgens, G. Mutations in the FASS gene uncouple pattern formation and morphogenesis in Arabidopsis development. Development 1994, 120, 2967-2978. [PubMed]

5. Berleth, T.; Jurgens, G. The role of the monopteros gene in organising the basal body region of the Arabidopsis embryo. Development 1993, 118, 575-587.

6. Hove, C.A.T.; Lu, K.-J.; Weijers, D. Building a plant: Cell fate specification in the early Arabidopsis embryo. Development 2015, 142, 420-430. [CrossRef] 
7. Petricka, J.J.; Van Norman, J.M.; Benfey, P.N. Symmetry Breaking in Plants: Molecular Mechanisms Regulating Asymmetric Cell Divisions in Arabidopsis. Cold Spring Harb. Perspect. Biol. 2009, 1, a000497. [CrossRef] [PubMed]

8. Menand, B.; Calder, G.; Dolan, L. Both chloronemal and caulonemal cells expand by tip growth in the moss Physcomitrella patens. J. Exp. Bot. 2007, 58, 1843-1849. [CrossRef] [PubMed]

9. Jang, G.; Yi, K.; Pires, N.D.; Menand, B.; Dolan, L. RSL genes are sufficient for rhizoid system development in early diverging land plants. Development 2011, 138, 2273-2281. [CrossRef] [PubMed]

10. Thelander, M.; Landberg, K.; Sundberg, E. Auxin-mediated developmental control in the moss Physcomitrella patens. J. Exp. Bot. 2018, 69, 277-290. [CrossRef] [PubMed]

11. Yoshida, S.; de Reuille, P.B.; Lane, B.; Bassel, G.W.; Prusinkiewicz, P.; Smith, R.S.; Weijers, D. Genetic Control of Plant Development by Overriding a Geometric Division Rule. Dev. Cell 2014, 29, 75-87. [CrossRef]

12. Serra, L.; Robinson, S. Plant cell divisions: Variations from the shortest symmetric path. Biochem. Soc. Trans. 2020, 48, 2743-2752. [CrossRef]

13. Coudert, Y.; Harris, S.; Charrier, B. Design Principles of Branching Morphogenesis in Filamentous Organisms. Curr. Biol. 2019, 29, R1149-R1162. [CrossRef] [PubMed]

14. Proust, H.; Hoffmann, B.; Xie, X.; Yoneyama, K.; Schaefer, D.G.; Nogué, F.; Rameau, C. Strigolactones regulate protonema branching and act as a quorum sensing-like signal in the moss Physcomitrella patens. Development 2011, 138, 1531-1539. [CrossRef] [PubMed]

15. Thelander, M.; Olsson, T.; Ronne, H. Effect of the energy supply on filamentous growth and development in Physcomitrella patens. J. Exp. Bot. 2004, 56, 653-662. [CrossRef]

16. Schmiedel, G.; Schnepf, E. Side branch formation and orientation in the caulonema of the moss, Funaria hygrometrica: Experiments with inhibitors and with centrifugation. Protoplasma 1979, 101, 47-59. [CrossRef]

17. Uenaka, H.; Wada, M.; Kadota, A. Four distinct photoreceptors contribute to light-induced side branch formation in the moss Physcomitrella patens. Planta 2005, 222, 623-631. [CrossRef] [PubMed]

18. Cheng, X.; Mwaura, B.W.; Stauffer, S.R.C.; Bezanilla, M. A Fully Functional ROP Fluorescent Fusion Protein Reveals Roles for This GTPase in Subcellular and Tissue-Level Patterning. Plant Cell 2020, 32, 3436-3451. [CrossRef]

19. Yi, P.; Goshima, G. Rho of Plants GTPases and Cytoskeletal Elements Control Nuclear Positioning and Asymmetric Cell Division during Physcomitrella patens Branching. Curr. Biol. 2020, 30, 2860-2868.e3. [CrossRef] [PubMed]

20. Harrison, C.J.; Roeder, A.H.; Meyerowitz, E.M.; Langdale, J.A. Local Cues and Asymmetric Cell Divisions Underpin Body Plan Transitions in the Moss Physcomitrella patens. Curr. Biol. 2009, 19, 461-471. [CrossRef] [PubMed]

21. Kosetsu, K.; Murata, T.; Yamada, M.; Nishina, M.; Boruc, J.; Hasebe, M.; Van Damme, D.; Goshima, G. Cytoplasmic MTOCs control spindle orientation for asymmetric cell division in plants. Proc. Natl. Acad. Sci. USA 2017, 114, E8847-E8854. [CrossRef] [PubMed]

22. Tang, H.; Duijts, K.; Bezanilla, M.; Scheres, B.; Vermeer, J.E.M.; Willemsen, V. Geometric cues forecast the switch from two- to three-dimensional growth in Physcomitrella patens. New Phytol. 2019, 225, 1945-1955. [CrossRef] [PubMed]

23. Moody, L.A. The 2D to 3D growth transition in the moss Physcomitrella patens. Curr. Opin. Plant Biol. 2019, 47, 88-95. [CrossRef]

24. Zagórska-Marek, B.; Sokołowska, K.; Turzańska, M. Chiral events in developing gametophores of Physcomitrella patens and other moss species are driven by an unknown, universal direction-sensing mechanism. Am. J. Bot. 2018, 105, 1986-1994. [CrossRef] [PubMed]

25. Véron, E.; Vernoux, T.; Coudert, Y. Phyllotaxis from a Single Apical Cell. Trends Plant Sci. 2021, 26, 124-131. [CrossRef] [PubMed]

26. Feiguelman, G.; Fu, Y.; Yalovsky, S. ROP GTPases Structure-Function and Signaling Pathways. Plant Physiol. 2018, 176, 57-79. [CrossRef] [PubMed]

27. Zhou, Z.; Shi, H.; Chen, B.; Zhang, R.; Huang, S.; Fu, Y. Arabidopsis RIC1 Severs Actin Filaments at the Apex to Regulate Pollen Tube Growth. Plant Cell 2015, 27, 1140-1161. [CrossRef]

28. Li, C.; Lu, H.; Li, W.; Yuan, M.; Fu, Y. A ROP2-RIC1 pathway fine-tunes microtubule reorganization for salt tolerance in Arabidopsis. Plant Cell Environ. 2017, 40, 1127-1142. [CrossRef] [PubMed]

29. Eklund, D.M.; Svensson, E.M.; Kost, B. Physcomitrella patens: A model to investigate the role of RAC/ROP GTPase signalling in tip growth. J. Exp. Bot. 2010, 61, 1917-1937. [CrossRef]

30. Humphries, J.A.; Vejlupkova, Z.; Luo, A.; Meeley, R.B.; Sylvester, A.W.; Fowler, J.E.; Smith, L.G. ROP GTPases Act with the Receptor-Like Protein PAN1 to Polarize Asymmetric Cell Division in Maize. Plant Cell 2011, 23, 2273-2284. [CrossRef]

31. Goldstein, B.; Macara, I.G. The PAR Proteins: Fundamental Players in Animal Cell Polarization. Dev. Cell 2007, 13, 609-622. [CrossRef] [PubMed]

32. Hiwatashi, T.; Goh, H.; Yasui, Y.; Koh, L.Q.; Takami, H.; Kajikawa, M.; Kirita, H.; Kanazawa, T.; Minamino, N.; Togawa, T.; et al. The RopGEF KARAPPO Is Essential for the Initiation of Vegetative Reproduction in Marchantia polymorpha. Curr. Biol. 2019, 29, 3525-3531.e7. [CrossRef] [PubMed]

33. Van Dop, M.; Fiedler, M.; Mutte, S.; de Keijzer, J.; Olijslager, L.; Albrecht, C.; Liao, C.-Y.; Janson, M.E.; Bienz, M.; Weijers, D. DIX Domain Polymerization Drives Assembly of Plant Cell Polarity Complexes. Cell 2020, 180, 427-439.e12. [CrossRef]

34. Yoshida, S.; Van Der Schuren, A.; Van Dop, M.; Van Galen, L.; Saiga, S.; Adibi, M.; Möller, B.; Hove, C.A.T.; Marhavy, P.; Smith, R.; et al. A SOSEKI-based coordinate system interprets global polarity cues in Arabidopsis. Nat. Plants 2019, 5, 160-166. [CrossRef] [PubMed] 
35. Tsuge, T.; Tsukaya, H.; Uchimiya, H. Two independent and polarized processes of cell elongation regulate leaf blade expansion in Arabidopsis thaliana (L.) Heynh. Development 1996, 122, 1589-1600. [PubMed]

36. Bai, Y.; Vaddepalli, P.; Fulton, L.; Bhasin, H.; Hülskamp, M.; Schneitz, K. ANGUSTIFOLIA is a central component of tissue morphogenesis mediated by the atypical receptor-like kinase STRUBBELIG. BMC Plant Biol. 2013, 13, 16. [CrossRef]

37. Shao, W.; Dong, J. Polarity in plant asymmetric cell division: Division orientation and cell fate differentiation. Dev. Biol. 2016, 419, 121-131. [CrossRef]

38. Liu, H.; Yu, H.; Tang, G.; Huang, T. Small but powerful: Function of microRNAs in plant development. Plant Cell Rep. 2018, 37, 515-528. [CrossRef]

39. Fletcher, J.C. Recent Advances in Arabidopsis CLE Peptide Signaling. Trends Plant Sci. 2020, 25, 1005-1016. [CrossRef]

40. Yamaguchi, Y.L.; Ishida, T.; Sawa, S. CLE peptides and their signaling pathways in plant development. J. Exp. Bot. 2016, 67, 4813-4826. [CrossRef]

41. Schoof, H.; Lenhard, M.; Haecker, A.; Mayer, K.F.; Jürgens, G.; Laux, T. The Stem Cell Population of Arabidopsis Shoot Meristems Is Maintained by a Regulatory Loop between the CLAVATA and WUSCHEL Genes. Cell 2000, 100, 635-644. [CrossRef]

42. Stahl, Y.; Simon, R. Peptides and receptors controlling root development. Philos. Trans. R. Soc. B Biol. Sci. 2012, 367, 1453-1460. [CrossRef]

43. Etchells, J.P.; Turner, S.R.; Perez-Alcala, S.; Nieto, M.A.; Barbas, J.A. The PXY-CLE41 receptor ligand pair defines a multifunctional pathway that controls the rate and orientation of vascular cell division. Development 2010, 137, 767-774. [CrossRef] [PubMed]

44. Hirakawa, Y.; Uchida, N.; Yamaguchi, Y.L.; Tabata, R.; Ishida, S.; Ishizaki, K.; Nishihama, R.; Kohchi, T.; Sawa, S.; Bowman, J.L. Control of proliferation in the haploid meristem by CLE peptide signaling in Marchantia polymorpha. PLoS Genet. 2019, 15, e1007997. [CrossRef]

45. Whitewoods, C.D.; Cammarata, J.; Venza, Z.N.; Sang, S.; Crook, A.D.; Aoyama, T.; Wang, X.Y.; Waller, M.; Kamisugi, Y.; Cuming, A.C.; et al. CLAVATA Was a Genetic Novelty for the Morphological Innovation of 3D Growth in Land Plants. Curr. Biol. 2018, 28, 2365-2376.e5. [CrossRef]

46. Smertenko, A. Phragmoplast expansion: The four-stroke engine that powers plant cytokinesis. Curr. Opin. Plant Biol. 2018, 46, 130-137. [CrossRef] [PubMed]

47. Müller, S. Plant cell division-Defining and finding the sweet spot for cell plate insertion. Curr. Opin. Cell Biol. 2019, 60, 9-18. [CrossRef]

48. Livanos, P.; Müller, S. Division Plane Establishment and Cytokinesis. Annu. Rev. Plant Biol. 2019, 70, 239-267. [CrossRef]

49. Buschmann, H.; Müller, S. Update on plant cytokinesis: Rule and divide. Curr. Opin. Plant Biol. 2019, 52, 97-105. [CrossRef] [PubMed]

50. Rasmussen, C.G.; Bellinger, M. An overview of plant division-plane orientation. New Phytol. 2018, 219, 505-512. [CrossRef] [PubMed]

51. Komis, G.; Luptovčiak, I.; Ovečka, M.; Samakovli, D.; Šamajová, O.; Šamaj, J. Katanin Effects on Dynamics of Cortical Microtubules and Mitotic Arrays in Arabidopsis thaliana Revealed by Advanced Live-Cell Imaging. Front. Plant Sci. 2017, 8, 866. [CrossRef]

52. Vos, J.W.; Dogterom, M.; Emons, A.M.C. Microtubules become more dynamic but not shorter during preprophase band formation: A possible "search-and-capture" mechanism for microtubule translocation. Cell Motil. Cytoskelet. 2004, 57, 246-258. [CrossRef] [PubMed]

53. Mineyuki, Y. The Preprophase Band of Microtubules: Its Function as a Cytokinetic Apparatus in Higher Plants. Adv. Appl. Microbiol. 1999, 187, 1-49. [CrossRef]

54. Chakrabortty, B.; Willemsen, V.; de Zeeuw, T.; Liao, C.-Y.; Weijers, D.; Mulder, B.; Scheres, B. A Plausible Microtubule-Based Mechanism for Cell Division Orientation in Plant Embryogenesis. Curr. Biol. 2018, 28, 3031-3043.e2. [CrossRef] [PubMed]

55. Louveaux, M.; Julien, J.-D.; Mirabet, V.; Boudaoud, A.; Hamant, O. Cell division plane orientation based on tensile stress in Arabidopsis thaliana. Proc. Natl. Acad. Sci. USA 2016, 113, E4294-E4303. [CrossRef] [PubMed]

56. Schaefer, E.; Belcram, K.; Uyttewaal, M.; Duroc, Y.; Goussot, M.; Legland, D.; Laruelle, E.; de Tauzia-Moreau, M.L.; Pastuglia, M.; Bouchez, D. The preprophase band of microtubules controls the robustness of division orientation in plants. Science 2017, 356, 186-189. [CrossRef]

57. Zhang, Y.; Iakovidis, M.; Costa, S. Control of patterns of symmetric cell division in the epidermal and cortical tissues of the Arabidopsis root. Development 2016, 143, 978-982. [CrossRef]

58. Doonan, J.H.; Cove, D.J.; Corke, F.M.K.; Lloyd, C.W. Pre-prophase band of microtubules, absent from tip-growing moss filaments, arises in leafy shoots during transition to intercalary growth. Cell Motil. Cytoskelet. 1987, 7, 138-153. [CrossRef]

59. Doonan, J.H.; Cove, D.J.; Lloyd, C.W. Immunofluorescence microscopy of microtubules in intact cell lineages of the moss, Physcomitrella patens. I. Normal and CIPC-treated tip cells. J. Cell Sci. 1985, 75, 131-147.

60. Spinner, L.; Pastuglia, M.; Belcram, K.; Pegoraro, M.; Goussot, M.; Bouchez, D.; Schaefer, D.G. The function of TONNEAU1 in moss reveals ancient mechanisms of division plane specification and cell elongation in land plants. Development 2010, 137, 2733-2742. [CrossRef]

61. Rasmussen, C.G.; Wright, A.J.; Mueller, S. The role of the cytoskeleton and associated proteins in determination of the plant cell division plane. Plant J. 2013, 75, 258-269. [CrossRef]

62. Kozgunova, E.; Yoshida, M.W.; Goshima, G. Spindle position dictates division site during asymmetric cell division in moss. bioRxiv 2020. [CrossRef] 
63. Wu, S.-Z.; Bezanilla, M. Myosin VIII associates with microtubule ends and together with actin plays a role in guiding plant cell division. eLife 2014, 3, e03498. [CrossRef] [PubMed]

64. Arima, K.; Tamaoki, D.; Mineyuki, Y.; Yasuhara, H.; Nakai, T.; Shimmen, T.; Yoshihisa, T.; Sonobe, S. Displacement of the mitotic apparatuses by centrifugation reveals cortical actin organization during cytokinesis in cultured tobacco BY-2 cells. J. Plant Res. 2018, 131, 803-815. [CrossRef]

65. Chugh, M.; Reißner, M.; Bugiel, M.; Lipka, E.; Herrmann, A.; Roy, B.; Müller, S.; Schäffer, E. Phragmoplast Orienting Kinesin 2 Is a Weak Motor Switching between Processive and Diffusive Modes. Biophys. J. 2018, 115, 375-385. [CrossRef]

66. Neuffer, M.G.; Sheridan, W.F. Defective Kernel Mutants of Maize. I. Genetic and Lethality Studies. Genetics 1980, 95, 929-944. [PubMed]

67. Lid, S.E.; Gruis, D.; Jung, R.; Lorentzen, J.A.; Ananiev, E.; Chamberlin, M.; Niu, X.; Meeley, R.; Nichols, S.; Olsen, O.-A. The defective kernel 1 (dek1) gene required for aleurone cell development in the endosperm of maize grains encodes a membrane protein of the calpain gene superfamily. Proc. Natl. Acad. Sci. USA 2002, 99, 5460-5465. [CrossRef] [PubMed]

68. Tran, D.; Galletti, R.; Neumann, E.D.; Dubois-Maheo, A.; Sharif-Naeini, R.; Geitmann, A.; Frachisse, J.-M.; Hamant, O.; Ingram, G.C. A mechanosensitive $\mathrm{Ca}^{2+}$ channel activity is dependent on the developmental regulator DEK1. Nat. Commun. 2017, 8 , 1009. [CrossRef]

69. Liang, Z.; Demko, V.; Wilson, R.C.; Johnson, K.A.; Ahmad, R.; Perroud, P.-F.; Quatrano, R.; Zhao, S.; Shalchian-Tabrizi, K.; Otegui, M.S.; et al. The catalytic domain CysPc of the DEK1 calpain is functionally conserved in land plants. Plant J. 2013, 75, 742-754 [CrossRef] [PubMed]

70. Johnson, K.L.; Faulkner, C.; Jeffree, C.E.; Ingram, G.C. The Phytocalpain Defective Kernel 1 Is a Novel Arabidopsis Growth Regulator Whose Activity Is Regulated by Proteolytic Processing. Plant Cell 2008, 20, 2619-2630. [CrossRef] [PubMed]

71. Galletti, R.; Johnson, K.L.; Scofield, S.; San-Bento, R.; Watt, A.M.; Murray, J.A.H.; Ingram, G.C. DEFECTIVE KERNEL 1 promotes and maintains plant epidermal differentiation. Development 2015, 142, 1978-1983. [CrossRef] [PubMed]

72. Perroud, P.-F.; Demko, V.; Johansen, W.; Wilson, R.C.; Olsen, O.-A.; Quatrano, R.S. Defective Kernel 1 (DEK1) is required for three-dimensional growth in Physcomitrella patens. New Phytol. 2014, 203, 794-804. [CrossRef] [PubMed]

73. Lid, S.E.; Olsen, L.; Nestestog, R.; Aukerman, M.; Brown, R.C.; Lemmon, B.; Mucha, M.; Opsahl-Sorteberg, H.-G.; Olsen, O.-A Mutation in the Arabidopisis thaliana DEK1 calpain gene perturbs endosperm and embryo development while over-expression affects organ development globally. Planta 2005, 221, 339-351. [CrossRef] [PubMed]

74. Becraft, P.W.; Li, K.; Dey, N.; Asuncion-Crabb, Y. The maize dek1 gene functions in embryonic pattern formation and cell fate specification. Development 2002, 129, 5217-5225. [PubMed]

75. Johansen, W.; Ako, A.E.; Demko, V.; Perroud, P.-F.; Rensing, S.A.; Mekhlif, A.K.; Olsen, O.-A. The DEK1 calpain Linker functions in three-dimensional body patterning in Physcomitrella patens. Plant Physiol. 2016, 172, 1089-1104. [CrossRef]

76. Demko, V.; Perroud, P.-F.; Johansen, W.; Delwiche, C.F.; Cooper, E.D.; Remme, P.; Ako, A.E.; Kugler, K.G.; Mayer, K.F.; Quatrano, R.; et al. Genetic Analysis of DEFECTIVE KERNEL1 Loop Function in Three-Dimensional Body Patterning in Physcomitrella patens. Plant Physiol. 2014, 166, 903-919. [CrossRef]

77. Perroud, P.; Meyberg, R.; Demko, V.; Quatrano, R.S.; Olsen, O.; Rensing, S.A. DEK1 displays a strong subcellular polarity during Physcomitrella patens 3D growth. New Phytol. 2020, 226, 1029-1041. [CrossRef] [PubMed]

78. Aoyama, T.; Hiwatashi, Y.; Shigyo, M.; Kofuji, R.; Kubo, M.; Ito, M.; Hasebe, M. AP2-type transcription factors determine stem cell identity in the moss Physcomitrella patens. Development 2012, 139, 3120-3129. [CrossRef]

79. Moody, L.A.; Kelly, S.; Rabbinowitsch, E.; Langdale, J.A. Genetic Regulation of the 2D to 3D Growth Transition in the Moss Physcomitrella patens. Curr. Biol. 2018, 28, 473-478.e5. [CrossRef] [PubMed]

80. Galinha, C.; Hofhuis, H.; Luijten, M.; Willemsen, V.; Blilou, I.; Heidstra, R.; Scheres, B. PLETHORA proteins as dose-dependent master regulators of Arabidopsis root development. Nat. Cell Biol. 2007, 449, 1053-1057. [CrossRef]

81. Aida, M.; Beis, D.; Heidstra, R.; Willemsen, V.; Blilou, I.; Galinha, C.; Nussaume, L.; Noh, Y.-S.; Amasino, R.; Scheres, B. The PLETHORA Genes Mediate Patterning of the Arabidopsis Root Stem Cell Niche. Cell 2004, 119, 109-120. [CrossRef]

82. Mähönen, A.P.; Tusscher, K.T.; Siligato, R.; Smetana, O.; Díaz-Triviño, S.; Salojärvi, J.; Wachsman, G.; Prasad, K.; Heidstra, R.; Scheres, B. PLETHORA gradient formation mechanism separates auxin responses. Nat. Cell Biol. 2014, 515, 125-129. [CrossRef]

83. Santuari, L.; Sanchez-Perez, G.F.; Luijten, M.; Rutjens, B.; Terpstra, I.; Berke, L.; Gorte, M.; Prasad, K.; Bao, D.; TimmermansHereijgers, J.L.; et al. The PLETHORA Gene Regulatory Network Guides Growth and Cell Differentiation in Arabidopsis Roots. Plant Cell 2016, 28, 2937-2951. [CrossRef] [PubMed]

84. Ashton, N.W.; Grimsley, N.H.; Cove, D.J. Analysis of gametophytic development in the moss, Physcomitrella patens, using auxin and cytokinin resistant mutants. Planta 1979, 144, 427-435. [CrossRef]

85. Causier, B.; Ashworth, M.; Guo, W.; Davies, B. The TOPLESS Interactome: A Framework for Gene Repression in Arabidopsis. Plant Physiol. 2011, 158, 423-438. [CrossRef]

86. Causier, B.; Lloyd, J.; Stevens, L.; Davies, B. TOPLESS co-repressor interactions and their evolutionary conservation in plants. Plant Signal. Behav. 2012, 7, 325-328. [CrossRef] [PubMed]

87. Eklund, D.M.; Ishizaki, K.; Flores-Sandoval, E.; Kikuchi, S.; Takebayashi, Y.; Tsukamoto, S.; Hirakawa, Y.; Nonomura, M.; Kato, H.; Kouno, M.; et al. Auxin Produced by the Indole-3-Pyruvic Acid Pathway Regulates Development and Gemmae Dormancy in the Liverwort Marchantia polymorpha. Plant Cell 2015, 27, 1650-1669. [CrossRef] [PubMed] 
88. Flores-Sandoval, E.; Eklund, D.M.; Bowman, J.L. A Simple Auxin Transcriptional Response System Regulates Multiple Morphogenetic Processes in the Liverwort Marchantia polymorpha. PLoS Genet. 2015, 11, e1005207. [CrossRef] [PubMed]

89. Kato, H.; Ishizaki, K.; Kouno, M.; Shirakawa, M.; Bowman, J.L.; Nishihama, R.; Kohchi, T. Auxin-mediated transcriptional system with a minimal set of components is critical for morphogenesis through the life cycle in Marchantia polymorpha. PLoS Genet. 2015, $11, \mathrm{e} 1005084$.

90. Kato, H.; Kouno, M.; Takeda, M.; Suzuki, H.; Ishizaki, K.; Nishihama, R.; Kohchi, T. The Roles of the Sole Activator-Type Auxin Response Factor in Pattern Formation of Marchantia polymorpha. Plant Cell Physiol. 2017, 58, 1642-1651. [CrossRef] [PubMed]

91. Kato, H.; Mutte, S.K.; Suzuki, H.; Crespo, I.; Das, S.; Radoeva, T.; Fontana, M.; Yoshitake, Y.; Hainiwa, E.; Berg, W.V.D.; et al. Design principles of a minimal auxin response system. Nat. Plants 2020, 6, 473-482. [CrossRef] [PubMed]

92. Kato, H.; Nishihama, R.; Weijers, D.; Kohchi, T. Evolution of nuclear auxin signaling: Lessons from genetic studies with basal land plants. J. Exp. Bot. 2017, 69, 291-301. [CrossRef]

93. Paponov, I.A.; Teale, W.; Lang, D.; Paponov, M.; Reski, R.; Rensing, S.A.; Palme, K. The evolution of nuclear auxin signalling. BMC Evol. Biol. 2009, 9, 126. [CrossRef] [PubMed]

94. Prigge, M.J.; Lavy, M.; Ashton, N.W.; Estelle, M. Physcomitrella patens Auxin-Resistant Mutants Affect Conserved Elements of an Auxin-Signaling Pathway. Curr. Biol. 2010, 20, 1907-1912. [CrossRef]

95. Rensing, S.A.; Lang, D.; Zimmer, A.D.; Terry, A.; Salamov, A.; Shapiro, H.; Nishiyama, T.; Perroud, P.-F.; Lindquist, E.A.; Kamisugi, Y.; et al. The Physcomitrella Genome Reveals Evolutionary Insights into the Conquest of Land by Plants. Science 2007, 319, 64-69. [CrossRef]

96. Sugano, S.S.; Shirakawa, M.; Takagi, J.; Matsuda, Y.; Shimada, T.; Hara-Nishimura, I.; Kohchi, T. CRISPR/Cas9-Mediated Targeted Mutagenesis in the Liverwort Marchantia polymorpha L. Plant Cell Physiol. 2014, 55, 475-481. [CrossRef] [PubMed]

97. Lavy, M.; Prigge, M.J.; Tigyi, K.; Estelle, M. The cyclophilin DIAGEOTROPICA has a conserved role in auxin signaling. Development 2012, 139, 1115-1124. [CrossRef] [PubMed]

98. Bennett, T.A.; Liu, M.M.; Aoyama, T.; Bierfreund, N.M.; Braun, M.; Coudert, Y.; Dennis, R.J.; O'Connor, D.; Wang, X.Y.; White, C.D.; et al. Plasma Membrane-Targeted PIN Proteins Drive Shoot Development in a Moss. Curr. Biol. 2014, 24, 2776-2785. [CrossRef]

99. Viaene, T.; Landberg, K.; Thelander, M.; Medvecka, E.; Pederson, E.; Feraru, E.; Cooper, E.D.; Karimi, M.; Delwiche, C.F.; Ljung, K.; et al. Directional auxin transport mechanisms in early diverging land plants. Curr. Biol. 2014, 24, 2786-2791. [CrossRef]

100. Blilou, I.; Xu, J.; Wildwater, M.; Willemsen, V.; Paponov, I.; Friml, J.; Heidstra, R.; Aida, M.; Palme, K.; Scheres, B. The PIN auxin efflux facilitator network controls growth and patterning in Arabidopsis roots. Nat. Cell Biol. 2005, 433, 39-44. [CrossRef]

101. Lavy, M.; Prigge, M.J.; Tao, S.; Shain, S.; Kuo, A.; Kirchsteiger, K.; Estelle, M. Constitutive auxin response in Physcomitrella reveals complex interactions between Aux/IAA and ARF proteins. eLife 2016, 5, 427. [CrossRef] [PubMed]

102. Lin, D.; Nagawa, S.; Chen, J.; Cao, L.; Chen, X.; Xu, T.; Li, H.; Dhonukshe, P.; Yamamuro, C.; Friml, J.; et al. A ROP GTPaseDependent Auxin Signaling Pathway Regulates the Subcellular Distribution of PIN2 in ArabidopsisRoots. Curr. Biol. 2012, 22, 1319-1325. [CrossRef]

103. Pan, X.; Fang, L.; Liu, J.; Senay-Aras, B.; Lin, W.; Zheng, S.; Zhang, T.; Guo, J.; Manor, U.; Van Norman, J.; et al. Auxin-induced signaling protein nanoclustering contributes to cell polarity formation. Nat. Commun. 2020, 11, 3914. [CrossRef]

104. Platre, M.P.; Bayle, V.; Armengot, L.; Bareille, J.; Marquès-Bueno, M.D.M.; Creff, A.; Maneta-Peyret, L.; Fiche, J.-B.; Nollmann, M.; Miège, C.; et al. Developmental control of plant Rho GTPase nano-organization by the lipid phosphatidylserine. Science 2019, 364, 57-62. [CrossRef] [PubMed]

105. Andersen, T.G.; Naseer, S.; Ursache, R.; Wybouw, B.; Smet, W.; De Rybel, B.; Vermeer, J.E.M.; Geldner, N. Diffusible repression of cytokinin signalling produces endodermal symmetry and passage cells. Nat. Cell Biol. 2018, 555, 529-533. [CrossRef]

106. Bishopp, A.; Help, H.; El-Showk, S.; Weijers, D.; Scheres, B.; Friml, J.; Benková, E.; Mähönen, A.P.; Helariutta, Y. A Mutually Inhibitory Interaction between Auxin and Cytokinin Specifies Vascular Pattern in Roots. Curr. Biol. 2011, 21, 917-926. [CrossRef]

107. Salvi, E.; Rutten, J.P.; Di Mambro, R.; Polverari, L.; Licursi, V.; Negri, R.; Ioio, R.D.; Sabatini, S.; Tusscher, K.T. A Self-Organized PLT/Auxin/ARR-B Network Controls the Dynamics of Root Zonation Development in Arabidopsis thaliana. Dev. Cell 2020, 53, 431-443.e23. [CrossRef] [PubMed]

108. Moody, L.A.; Kelly, S.; Clayton, R.; Weeks, Z.; Emms, D.M.; Langdale, J.A. Article NO GAMETOPHORES 2 Is a Novel Regulator of the 2D to 3D Growth Transition in the Moss Physcomitrella patens. Curr. Biol. 2021, 31, 555-563.e4. [CrossRef] 